\title{
PENGEMBANGAN LEMBAR KERJA PESERTA DIDIK BERBASIS MOODLE MATERI PENGUKURAN PANJANG KELAS IV SEKOLAH DASAR
}

\author{
Aliffirda Zulinar ${ }^{1 *}$, Iva Sarifah', Andi Ali Saladin ${ }^{3}$ \\ ${ }^{1,2,3}$ Universitas Negeri Jakarta, Indonesia \\ *Corresponding Author: @alfizulinar@gmail.com
}

\begin{tabular}{l} 
Info Artikel \\
\hline Sejarah Artikel: \\
Diterima: $11 / 10 / 2021$ \\
Direvisi: 16/10/2021 \\
Disetujui:20/10/2021 \\
\hline Keywords: \\
Student Worksheet, \\
Moodle, Mathematics, \\
Measuring length \\
\hline \\
Kata Kunci: \\
Lembar Kerja Peserta \\
Didik, Moodle, \\
Matematika, Pengukuran \\
Panjang \\
\hline
\end{tabular}

\begin{abstract}
This study aims to develop student worksheets for measuring length for grade IV Elementary Schools based on Moodle.This research is a development research using the ADDIE model. Data in this study were obtained through questionnaires and interviews. The subjects of this study were primary school students grade IV-B at SDN Baru 08 Pagi. This study involved three experts as validators of media eligibility, including media experts, content experts, and language experts. The results of these study indicate that the development of student worksheet based on Moodle has a significant level of eligibility assessment. The results of the validation of the content experts showed the eligibility with a percentage of $91 \%$, media experts with $85 \%$ and language experts at $90 \%$ of which all three were categorized in the "Very Eligible" criteria. The results of the trials to students also showed the same thing, where the two trials conducted showed each of the results of face to face tryout with an assessment of the eligibility percentage of $94 \%$ and field trial of 93,6\% which makes the media fall within the "Very Eligible" criteria. It can be said that the developed student worksheet based Moodle in mathematic of grade IV primary school.
\end{abstract}

Abstrak. Penelitian ini bertujuan untuk mengembangkan Lembar Kerja Peserta Didik (LKPD) materi pengukuran panjang untuk kelas IV Sekolah Dasar berbasis Moodle. Penelitian ini merupakan penelitian pengembangan menggunakan model ADDIE. Data pada penelitian ini diperoleh melalui angket dan wawancara. Subjek penelitian ini adalah peserta didik kelas IV-B di SDN Baru 08 Pagi, Jalan Sawo, Kelurahan Baru, Kecamatan Pasar Rebo, Jakarta Timur. Penelitian ini melibatkan tiga ahli sebagai validator kelayakan media, diantaranya adalah ahli media, ahli materi, dan ahli bahasa. Hasil pada penelitian ini menunjukkan pengembangan LKPD berbasis Moodle pembelajaran memiliki tingkat penilaian kelayakan yang sangat layak. Hasil validasi dari ahli materi menunjukkan kelayakan dengan persentase $91 \%$, ahli media dengan $85 \%$ dan ahli bahasa sebesar $90 \%$ yang mana ketiganya dikategorikan pada kriteria "Sangat Layak". Hasil dari ujicoba kepada peserta didik pun menunjukkan hal yang sama, di mana dari kedua ujicoba yang dilakukan menunjukkan masing-masing hasil dari face to face tryout dengan penilaian persentase kelayakan 94\% dan ujicoba lapangan sebesar 93,6\% yang menjadikan media berada di dalam kriteria "Sangat Layak". Dapat dikatakan lembar kerja peserta didik yang dikembangkan dapat digunakan dalam pembelajaran pada materi pengukuran panjang pada matematika kelas IV SD.

How to Cite: Zulinar,A., Sarifah,I., \& Saladin, A.A. (2022). PENGEMBANGAN LEMBAR KERJA PESERTA DIDIK BERBASIS MOODLE MATERI PENGUKURAN PANJANG KELAS IV SEKOLAH DASAR. Prima Magistra: Jurnal Ilmiah Kependidikan, 3(1), 16-29. https://doi.org/10.37478/jpm.v3i1.1290

Alamat korespondensi:

Jl. Taman Setia Budi I No.2, RW.2, Kuningan, Kecamatan Setiabudi, Kota Jakarta Selatan, Daerah Khusus Ibukota Jakarta 12910. alfizulinar@gmail.com
Penerbit:

Program Studi PGSD Universitas Flores.

Q) primagistrauniflor@gmail.com 


\section{PENDAHULUAN}

Covid-19 merupakan wabah penyakit yang menyerang sistem pernafasan dan menjangkit hampir seluruh wilayah di Indonesia, sehingga pemerintah menyatakan bahwa wabah Covid-19 merupakan pandemi di Indonesia. Dalam rangka pencegahan penularan Covid-19 di masyarakat, Kementerian Pendidikan dan Kebudayaan (Kemendikbud) menerbitkan beberapa surat edaran terkait pencegahan dan penanganan Covid-19 guna melindungi warga sekolah dari paparan Covid-19, berbagai wilayah menetapkan kebijakan belajar dari rumah. Kebijakan tersebut menyasar ke seluruh jenjang pendidikan (Arifa, 2020).

Dampak Covid-19 terhadap dunia pendidikan sangat besar dan dirasakan oleh berbagai pihak, terutama para guru, kepala sekolah, peserta didik dan juga orang tua (Sari, Tusyantari \& Suswandari, 2021). Kebijakan belajar dari rumah dilakukan melalui Pembelajaran Jarak Jauh (PJJ) diterapkan mulai dari tingkat Sekolah dasar sampai tingkat Perguruan Tinggi (Fredy, Prihandoko \& Anggawirya, 2020).

Dalam situasi pandemi Covid-19, penguasaan teknologi dalam proses pembelajaran daring (dalam jaringan) sangat penting dalam menggantikan pembelajaran langsung secara tatap muka di kelas. Di tingkat sekolah dasar, mata pelajaran yang sangat terpengaruh oleh pandemi Covid-19 adalah matematika (Fredy, Prihandoko \& Anggawirya, 2020).

Matematika memiliki peranan penting dalam berbagai aspek kehidupan. Banyak permasalahan dan kegiatan dalam hidup yang harus diselesaikan dengan menggunakan ilmu matematika seperti menghitung, mengukur, dan lain sebagainya. Selain itu, sekarang banyak informasi yang disampaikan dalam bahasa matematika seperti tabel, grafik, diagram, dan sebagainya sehingga matematika penting untuk dikuasai. Mengingat besarnya peranan matematika, maka tak heran jika pelajaran matematika diberikan pada setiap jenjang pendidikan (Tarigan, Rangkuti \& Siregar, 2017). Hal ini dikarenakan matematika merupakan metode berpikir logis, kritis, kreatif, keteraturan, seni, dan bahasa yang tidak hanya membantu dalam ilmu dan teknologi tetapi juga pembentukan keuletan, karakter, dan kepribadian peserta didik (Restianti, 2019).

Pada kenyataannya saat ini, matematika semakin menjadi sulit di tengah pandemi karena dinilai peserta didik semakin abstrak. Penyampaian materi hanya dilakukan dalam bentuk tugas-tugas yang dikirim oleh pendidik ke peserta didik dan peserta didik dituntut untuk memahami materi sendiri melalui tugas-tugas yang dikerjakan. Hal ini dibuktikan oleh data dari KPAI (Komisi Perlindungan Anak Indonesia) yang berjudul "Survei Pelaksanaan Pembelajaran Jarak Jauh (PJJ) dan Sistem Penilaian Jarak Jauh Berbasis Pengaduan KPAI" tahun 2020 (KPAI, 2020). Kondisi ini dinilai sangat memprihatinkan dalam proses pembelajaran daring selama pandemi Covid-19.

Situasi pandemi ini menjadi tantangan bagi dunia pendidikan. Pendidik harus berani menjadi agen perubahan (agent of change) untuk menjadikan pembelajaran daring menjadi lebih bermakna dan memberi kesempatan mentransformasi pendidikan di Indonesia. Oleh karena itu, inovasi dari seorang pendidik sangat diperlukan agar sektor pendidikan tidak tertinggal dalam kondisi ini. Pendidik sebagai penggerak proses pembelajaran harus memiliki kemampuan dan kreativitas dalam mengembangkan media pembelajaran untuk mewujudkan pembelajaran yang lebih bermakna dalam kondisi pandemi Covid-19.

Lembar Kerja Peserta Didik (LKPD) merupakan salah satu media pembelajaran yang dapat dikembangkan oleh pendidik sebagai fasilitator dalam kegiatan belajar mengajar (Widjajanti, 2008; Aryani, \& Hiltrimartin, 2011). LKPD dapat disusun, dirancang, dan dikembangkan sesuai dengan kondisi dan situasi kegiatan pembelajaran yang akan dihadapi.

Dengan kondisi yang tidak memungkinkan untuk menjalankan proses pembelajaran secara tatap muka menuntut pendidik untuk mengembangkan LKPD. Perkembangan teknologi di abad ke-21 yang telah melesat jauh dapat meningkatkan proses 
kegiatan pembelajaran tidak hanya terpaku pada LKPD yang dicetak di atas kertas dan kegiatan di dalam kelas.

Selama ini Lembar Kerja Peserta Didik (LKPD) dikenal sebagai bahan ajar berbentuk cetak dan peserta didik diarahkan menuliskan jawaban di atasnya, pada pengembangan Lembar Kerja Peserta Didik (LKPD) dapat disajikan dalam bentuk elektronik bukan hanya menyajikan materi, tetapi dilengkapi juga dengan aktivitas dan gambar-gambar menarik yang dapat meningkatkan atau menguatkan pemahaman peserta didik dalam mempelajari materi yang disampaikan. Untuk mendukung pembelajaran matematika seperti diatas digunakan LKPD non-cetak menggunakan aplikasi Moodle. Penelitian oleh Renata D.N Damanik yang berjudul "Tata Kelola Pelaksanaan E-Learning dalam Peningkatan Kinerja Penyelenggaraan Pelatihan dalam Masa Covid-19" tahun 2020 menunjukkan bahwa pembelajaran melalui LMS (Learning Management System), dalam penelitian ini adalah Moodle, akan mewujudkan proses pembelajaran yang semakin baik.

Penelitian sebelumnya oleh Widodo (2017) menunjukkan bahwa LKPD cetak yang digunakan dalam proses pembelajaran sangat baik diterapkan bagi peserta didik tingkat sekolah dasar. Hal itu ditunjukkan dengan komponen yang memperoleh skor paling tinggi adalah teknik penyajian, ukuran dan jenis kertas, desain sampul dan desain isi. Berbeda dengan kondisi di tengah pandemi Covid-19 yang sangat banyak menelan korban, pemanfaatan teknologi informasi diharapkan mampu menunjang LKPD noncetak bagi pembelajaran peserta didik. Oleh karena itu, berusaha dikembangkan LKPD yang diaplikasikan kedalam suatu aplikasi pembelajaran yang disebut dengan Moodle.

LKPD berbasis Moodle tidak mengharuskan peserta didik untuk hadir di dalam kelas. Penggunaannya dapat diakses melalui laptop dan smartphone sehingga pembelajaran jarak jauh dapat tetap terlaksana melalui LKPD berbasis Moodle. Proses pembelajaran dapat berlangsung sesuai alokasi waktu yang telah ditentukan oleh pendidik dan peserta didik. Pendidik dan peserta didik memerlukan teknologi yang dapat menyediakan layanan pendidikan yang persiapannya lebih singkat dan dapat diakses dari jarak jauh.

Berdasarkan wawancara yang dilakukan kepada para peserta didik pada kelas IV SDN Baru 08 Pagi diketahui bahwa seluruh peserta didik memiliki smartphone, walaupun tidak semuanya milik pribadi. Terdapat peserta didik yang dapat menggunakan smartphone milik orang tua saat mengikuti kegiatan pembelajaran. Hal ini dapat menjadi keuntungan tersendiri jika tersedia LKPD yang layak digunakan dalam pembelajaran online.

Masalah yang dimiliki adalah perlunya LKPD yang dapat diakses secara daring untuk menunjang proses pembelajaran dalam kondisi pandemi Covid-19. Dunia pendidikan memerlukan cara lain menjawab tantangan dalam dunia pendidikan. Pendidik dan peserta didik membutuhkan layanan baru yang dapat menyediakan pembelajaran jarak jauh yang pengadaannya cepat, metodenya efektif dan persiapannya lebih singkat.

Hasil wawancara dengan salah satu orang tua peserta didik ditemukan informasi bahwa penggunaan Lembar Kerja Peserta Didik (LKPD) sudah pernah digunakan tetapi dalam bentuk cetak dan belum pernah menggunakan LKPD berbasis Moodle. Orang tua peserta didik tersebut juga mengatakan belum pernah menggunakan aplikasi Moodle selama anaknya menjalani proses pembelajaran jarak jauh.

Pendidik sebagai perencana pembelajaran harus memiliki kemampuan memilih dan menerapkan alat bantu pembelajaran yang dapat membantu menyampaikan materi pembelajaran sehingga dapat meningkatkan pemahaman konsep terhadap peserta didik dan meningkatkan keaktifan peserta didik dalam proses pembelajaran. LKPD berbasis Moodle merupakan salah satu pengembangan yang dapat membantu penyampaian materi pembelajaran dalam situasi pandemi Covid-19 yang mengharuskan pendidik dan peserta didik belajar dari rumah. 
Pengembangan LKPD berbasis Moodle juga tidak jauh dari kekurangan-kekurangan. Kekurangan yang dimiliki pengembangan LKPD berbasis Moodle adalah dibutuhkannya pemahaman tenaga ahli yang mampu mengoperasikan dan menjalankan e-learning. Penggunaan e-learning sangat erat kaitannya dengan jaringan internet, sehingga penggunaan LKPD berbasis Moodle memerlukan akses jaringan internet yang cukup untuk menunjang. Penggunaan internet dan gawai membuat LKPD berbasis Moodle menjadi terbatas penggunaannya dan hanya bisa diakses bagi peserta didik yang memiliki smartphone dan jaringan internet.

Kebaruan penelitian yang membedakan penelitian ini dengan penelitian-penelitian sebelumnya adalah pada penelitian ini mengembangkan LKPD yang menggunakan aplikasi Moodle. Penelitian sebelumnya oleh Selfia (2019) menerapkan LKPD yang bersifat cetak yang sulit diterapkan dalam kondisi pandemi, namun dengan LKPD berbasis Moodle yang dapat diakses dari jarak jauh dengan bantuan jaringan internet yang dapat diterapkan dalam situasi pandemi Covid-19, peserta didik dapat mengerjakan LKPD tanpa harus tatap muka dengan pendidik. Selain itu, dalam LKPD berbasis Moodle ini belum ada penelitian sebelumnya yang menerapkannya dalam pembelajaran matematika jenjang sekolah dasar. Penelitian sebelumnya oleh Tumijan \& Purwanto (2019) menerapkannya pada pembelajaran IPA.

Bagian paling penting dari produk pengembangan ini adalah dikembangkan ditinjau dari aspek kebutuhan. Beberapa alasan mengapa pengembangan ini sangat dibutuhkan pada kondisi pembelajaran jarak jauh untuk menunjang proses pembelajaran adalah 1) pembelajaran akan lebih menarik perhatian peserta didik selama proses PJJ (Pembelajaran Jarak Jauh), 2) peserta didik lebih banyak melakukan kegiatan belajar, tidak hanya mengerjakan tugas, namun seperti melakukan kegiatan-kegiatan mandiri dalam LKPD mengenai materi, dan 3) mengurangi tingkat kejenuhan peserta didik dalam proses pembelajaran jarak jauh karena LKPD memuat gambar-gambar, langkah pengerjaan, dan forum diskusi dalam setiap sub submateri.
Berdasarkan uraian latar belakang di atas maka diperlukan solusi dengan upaya perbaikan pembelajaran melalui penelitian Research and Development (R\&D) untuk materi Pengukuran Panjang Kelas IV Sekolah Dasar dengan harapan mampu membantu proses pembelajaran jarak jauh selama pandemi Covid-19.

\section{METODE PENELITIAN}

Penelitian ini menggunakan metode penelitian dan pengembangan (Research and Development). Tujuan dari penelitian dan pengembangan ini adalah untuk menghasilkan produk Lembar Kerja Peserta Didik berbasis aplikasi Moodle pada materi Pengukuran Panjang di kelas IV (empat) Sekolah Dasar dan mengetahui kelayakan produk yang dikembangkan. LKPD ini dikembangkan dengan model ADDIE. Model ini terdiri atas lima langkah yaitu, 1) analyze, 2) design, 3) development, 4) implementation, dan 5) evaluation (Branch, 2009). Pemilihan model ini didasari pada alasan bahwa tahapantahapan dasar desain pengembangan ADDIE sederhana, mudah dipelajari, simpel serta lebih mudah dipraktikan dalam pengembangan media pembelajaran.

Penelitian ini dilakukan pada siswa kelas IV SDN Baru 08 Pagi, Kelurahan Baru, Kecamatan Pasar Rebo, Jakarta Timur. Penelitian dilaksanakan pada semester genap tahun ajaran 2020/2021 pada bulan Juli Agustus 2021. SDN Baru 08 Pagi dipilih sebagai lokasi penelitian karena lokasinya berdekatan dengan tempat tinggal dan telah menerapkan Kurikulum 2013.

Teknik pengumpulan data yang digunakan dalam penelitian dan pengembangan ini adalah dokumentasi, kuesioner, dan wawancara. Instrumen yang digunakan dalam penelitian dan pengembangan ini menggunakan wawancara dan kuesioner. Pada tahap analisis kebutuhan menggunakan instrumen wawancara. Pada tahap validasi produk oleh ahli media, ahli materi dan ahli bahasa menggunakan instrumen kuesioner.

Kriteria perhitungan yang digunakan adalah dengan membagi jumlah skor dari pengumpulan data dengan hasil kali jumlah 
butir soal dan jumlah butir soal dan jumlah poin tertinggi soal, kemudian hasilnya dikalikan dengan $100 \%$.

Skor hasil pengumpulan data

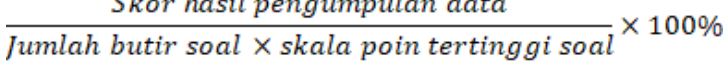

Setelah didapat hasil dari perhitungan skor, skor rata-rata yang diperoleh diubah menjadi nilai kualitatif yang sesuai dengan kriteria penilaian pada tabel.

Tabel 1. Skala Kelayakan Produk

\begin{tabular}{cc}
\hline $\begin{array}{c}\text { Skor Kelayakan } \\
\text { Media Pembelajaran }\end{array}$ & Kriteria \\
\hline $0 \%-20 \%$ & Sangat Kurang Layak \\
$20,01-40 \%$ & Kurang Layak \\
$40,01 \%-60 \%$ & Cukup Layak \\
$60,01 \%-80 \%$ & Layak \\
$80,01 \%-100 \%$ & Sangat Layak \\
\hline
\end{tabular}

Sumber: (Damayanti et.al, 2018)

Setelah diperoleh kriteria kelayakan produk, hasil perhitungannya dianalisis. Analisis data dalam penelitian dan pengembangan ini menerapkan teknik analisis model Miles dan Huberman. Miles dan Huberman membuat model analisis data yang terdiri dari tiga tahapan, yaitu: reduksi data (data reduction), penyajian data (data display), dan penarikan kesimpulan (conclusion) (Mardawani, 2020).

\section{HASIL DAN PEMBAHASAN}

Hasil

Berdasarkan hasil evaluasi expert review tersebut didapat kelayakan untuk media sebesar $85 \%$, kelayakan bahasa $90 \%$, dan kelayakan materi sebesar $91 \%$. Hasil ratarata kelayakan melalui evaluasi expert review untuk LKPD ini adalah sebesar $88,46 \%$ dan termasuk dalam kriteria "sangat layak".

Tabel 2. Hasil Rekapitulasi Ahli Media, Ahli Bahasa, dan Ahli Materi

\begin{tabular}{lllll}
\hline Responden & $\begin{array}{c}\text { Jumlah } \\
\text { butir }\end{array}$ & $\begin{array}{c}\text { Skor } \\
\text { Maksi- } \\
\text { mal }\end{array}$ & $\begin{array}{c}\text { Skor } \\
\text { Perole- } \\
\text { han }\end{array}$ & Persentase \\
\hline Ahli Media & 15 & 60 & 51 & $85 \%$ \\
Ahli Bahasa & 10 & 40 & 36 & $90 \%$ \\
Ahli Materi & 14 & 56 & 51 & $91 \%$
\end{tabular}

Rata-Rata Kelayakan dari Expert Review $88,46 \%$

Setelah dilakukan revisi produk, selanjutnya adalah tahap implementasi. Pada tahap ini dilakukan uji coba produk, melalui uji coba ini dilakukan pada 27 responden peserta didik kelas IV SD. Tahap implementasi terdiri dari 2 tahap penelitian, yaitu pertama tahap face to face tryout yang melibatkan 3 orang peserta didik SDN Baru 08 Pagi. Untuk tahap kedua yaitu uji lapangan (field trial) menggunakan 24 orang peserta didik karena 3 orang peserta didik yang telah digunakan dalam tahap face to face tryout sudah tidak dilibatkan kembali.

Tahap implementasi pertama pada penelitian ini adalah Face to Face Tryout. Uji coba kelayakan ini melibatkan tiga orang peserta didik untuk melakukan penilaian terhadap LKPD dengan menggunakan kuesioner. Penentuan responden pada Face to Face Tryout ini merupakan perwakilan peserta didik yang memiliki kemampuan rendah, sedang, dan tinggi yang berdomisili tidak jauh dari sekolah karena bertujuan untuk memudahkan dalam melakukan tahap Face to Face Tryout. Tahap Face to Face Tryout dilakukan pada tanggal 11 Agustus 2021.

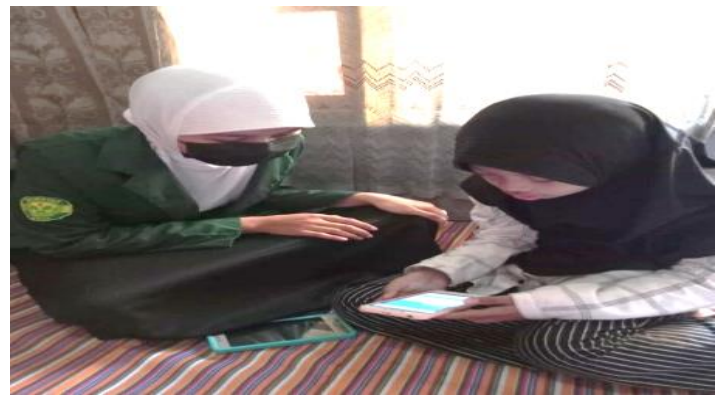

Gambar 1: Tahap Face to Face Tryout (Sumber: Dokumentasi Pribadi)

Berdasarkan hasil pengisian kuesioner didapatkan hasil sebagai berikut:

Tabel 3. Hasil Face to Face Tryout

\begin{tabular}{lclll}
\hline No. & $\begin{array}{c}\text { Nama } \\
\text { Peserta } \\
\text { Didik }\end{array}$ & $\begin{array}{c}\text { Skor } \\
\text { Maksimal }\end{array}$ & $\begin{array}{c}\text { Skor } \\
\text { Perolehan }\end{array}$ & Persentase \\
\hline 1. & GNMR & 11 & 11 & $100 \%$ \\
2. & MWRA & 11 & 10 & $91 \%$ \\
3. & MAA & 11 & 10 & $91 \%$ \\
\hline \multicolumn{4}{c}{ Rata-Rata Kelayakan dari Expert } \\
Review & $94 \%$ \\
\hline
\end{tabular}

Tahap terakhir dalam implementasi adalah field Trial. Uji coba ini dilaksanakan pada 19 Agustus 2021. Uji coba ini menggunakan produk yang sama dengan produk yang digunakan pada tahap Face to Face Tryout. Uji coba lapangan dilaksanakan kepada 24 orang peserta didik kelas IV-B SDN Baru 08 Pagi. 


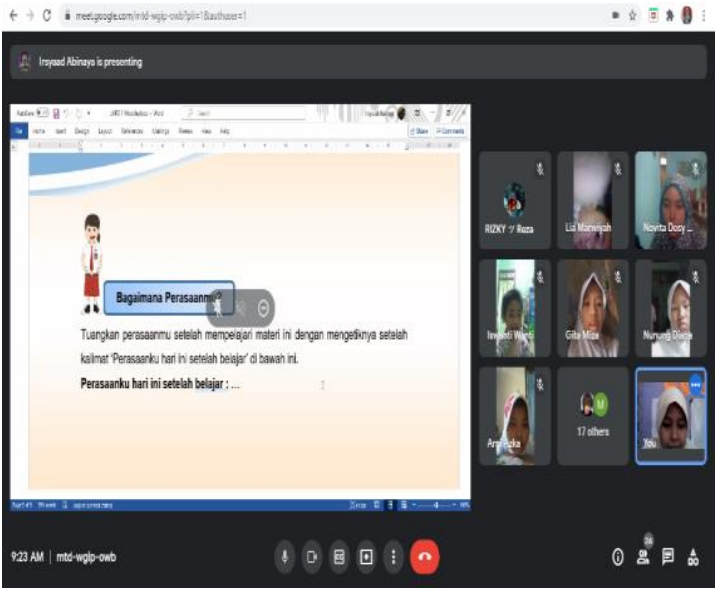

Gambar 2: Field Trial (sumber: dokumentasi pribadi)

Uji coba ini adalah dengan mengerjakan aktivitas dalam LKPD. Pelaksanaannya yang virtual melalui Google Meet mengarahkan peserta didik untuk mendengarkan cara penggunaan LKPD terlebih dulu sebelum mereka mencoba mandiri dengan pendamping belajar mereka di rumah. Langkah ini dipilih karena sebagian besar peserta didik tidak memiliki dua ponsel yang dapat digunakan bersamaan (satu ponsel untuk pertemuan virtual dan satu ponsel untuk mengerjakan).

Berikut ini adalah hasil rekapitulasi pada tahap Field Trial adalah sebagai berikut:

Tabel 4. Hasil Field Trial Peserta Didik

\begin{tabular}{ccc}
\hline No. & Responden & Rerata \\
\hline 1. & AAN & $100 \%$ \\
2. & AF & $82 \%$ \\
3. & AR & $91 \%$ \\
4. & AI & $100 \%$ \\
5. & ARA & $91 \%$ \\
6. & CFA & $91 \%$ \\
7. & CPA & $100 \%$ \\
8. & DS & $100 \%$ \\
9. & KAP & $100 \%$ \\
10. & LBP & $100 \%$ \\
11. & MA & $73 \%$ \\
12. & MRH & $100 \%$ \\
13. & MRK & $73 \%$ \\
14. & NN & $91 \%$ \\
15. & NS & $100 \%$ \\
16. & NNS & $91 \%$ \\
17. & QAK & $100 \%$ \\
18. & RRA & $82 \%$ \\
19. & RS & $100 \%$ \\
20. & RS & $91 \%$ \\
21. & RRAF & $100 \%$ \\
22. & SMNM & $100 \%$ \\
23. & TSL & $91 \%$ \\
24. & SW & $100 \%$ \\
\hline & & \\
\hline & &
\end{tabular}

Berdasarkan hasil rekapitulasi data yang diperoleh, maka didapatkan nilai ratarata dari tahap ini sebesar 93,6\% yang artinya sangat layak. Pada tahap ini tidak didapatkan perbaikan dan saran perbaikan dari peserta didik. Pada tahap field trial, sejalan dengan tanggapan peserta didik terhadap produk, pendidik juga memberikan tanggapan positif terhadap pengembangan LKPD. Skor perolehan tanggapan pendidik terhadap produk adalah sebesar $91,6 \%$.

\section{Pembahasan}

Penelitian dan pengembangan ini menghasilkan sebuah produk Lembar Kerja Peserta Didik yang bersifat non-cetak untuk kelas IV SD yang telah disesuaikan dengan kebutuhan belajar peserta didik. Menurut Dermawati, LKPD yang bertujuan agar peserta didik dapat lebih mudah memahami konsep materi yang disajikan dan mengajak peserta didik untuk aktif dalam pembelajaran (Dermawati et al., 2019). Penelitian ini mendukung pengembangan LKPD yang tengah dikembangkan oleh peneliti. Model pengembangan yang digunakan dalam penelitian ini adalah model pengembangan ADDIE. ADDIE memiliki 5 tahapan yaitu analyze, design, development, implemention, dan evaluation.

\section{Tahap Analisis (Analyze)}

Pada tahap Analyze meliputi: 1) Melakukan analisis kebutuhan pendidik dan peserta didik, 2) mengidentifikasi dan menentukan ruang lingkup unit dan kompetensi yang akan dicapai, 3) menentukan judul LKPD yang akan dikembangkan, dan 4) penyusunan draf.

Analisis kebutuhan pendidik dan peserta didik dilakukan untuk mengetahui kebutuhan pendidik dan peserta didik untuk mengembangkan LKPD yang sesuai dengan kebutuhan pendidik dan peserta didik. Analisis kebutuhan melibatkan kepada seorang pendidik kelas IV-B dan tiga peserta didik kelas IV-B SDN Baru 08 Pagi, Jalan Sawo, Kelurahan Baru, Kecamatan Pasar Rebo, Jakarta Timur. Berdasarkan data tersebut bahwa matematika merupakan mata pelajaran yang cukup sulit dan belum pernah digunakan LKPD dalam pembelajaran baik 
saat pembelajaran tatap muka di dalam kelas maupun pembelajaran jarak jauh. Melihat manfaat Lembar Kerja Peserta Didik pada bab II, pengembangan LKPD ini dapat menjadi terobosan baru dalam dunia pendidikan dengan memanfaatkan teknologi untuk menunjang proses pembelajaran.

Peserta didik juga mengalami kendala dalam memahami soal karena soal-soal yang diberikan kurang aplikatif dengan kehidupan peserta didik. Di lain sisi, pendidik tidak lepas tangan, pendidik tetap mengajar dengan pertemuan virtual dengan bantuan aplikasi Google Meet, walaupun soal-soal yang diberikan kurang menyesuaikan dengan kondisi peserta didik.

Setelah mendapat analisis kebutuhan berdasarkan observasi dan wawancara, selanjutnya adalah menentukan ruang lingkup dan kompetensi yang akan dicapai oleh peserta didik. Penyusunan ruang lingkup dan kompetensi bertujuan agar materi yang disampaikan tidak terlalu luas dan dibatasi dalam kompetensi tersebut. Penentuan ini diperlukan agar pendidik dan peserta didik memahami batas yang perlu dicapai dalam pembelajaran. Penentuan ini diperlukan tidak hanya untuk membatasi namun juga dijadikan arah tujuan pembelajaran.

Selanjutnya adalah menentukan judul LKPD yang dikembangkan. Berdasarkan hasil yang diperoleh, maka dipilih judul 'Lembar Kerja Peserta Didik Berbasis Moodle Materi Pengukuran Panjang Kelas IV SD'. Judul ini tercantum dalam LKPD itu sendiri dan juga tercantum dalam LMS Moodle yang nantinya akan diakses oleh peserta didik. Penulisan judul akan tercetak pada halaman sampul LKPD.

Tahap berikutnya adalah penyusunan draf yang disesuaikan dengan kebutuhan pendidik dan peserta didik yang diperoleh berdasarkan hasil wawancara dan hasil observasi. Secara garis besar, hasil dari analisis kebutuhan menunjukkan bahwa terdapat 3 kebutuhan yaitu media yang kurang bervariasi, soal-soal dan kegiatan yang langsung mengarahkan peserta didik untuk langsung menanamkan pemahamannya, dan penggunaan beberapa aplikasi yang dilihat cukup merepotkan pendidik karena memenuhi room chat pendidik, padahal personal chat akan lebih efektif bila khusus membahas mengenai percakapan pribadi antara pendidik, peserta didik, dan orang tua peserta didik.

\section{Tahap Desain (Design)}

Langkah selanjutnya yang adalah tahap desain. Tahap desain dilakukan dengan tujuan untuk merancang produk LKPD sesuai dengan kebutuhan pendidik dan peserta didik, sehingga LKPD yang dikembangkan bisa digunakan oleh peserta didik.

Secara keseluruhan, LKPD ini mengkombinasikan aktivitas yang mengajak peserta didik untuk duduk tenang dan bergerak. Hal ini senada yang dipaparkan oleh Meriyati dalam bukunya, pendidik hendaknya mengembangkan pembelajaran yang mengarahkan peserta didik untuk tidak duduk rapi untuk jangka waktu yang lama, dirasakan peserta didik sebagai siksaan (Meriyati, 2015).

Pengembangan LKPD ini juga mengarahkan peserta didik untuk mampu menyimpulkan aktivitas yang telah peserta didik kerjakan. Peserta didik diarahkan untuk lebih aktif karena pembelajaran yang mengarahkan peserta didik terlibat dalam meningkatkan kreativitas, melakukan kegiatan ilmiah dan berpikir kritis agar mampu menyimpulkan aktivitas yang telah dilaluinya dalam bahasa mereka sendiri di bagian yang telah disediakan. Keterlibatan peserta didik secara aktif sangat penting karena membuat peserta didik lebih produktif (Aydede, 2010).

Pengembangan juga memberi kesempatan peserta didik menyampaikan perasaannya dalam bentuk kalimat. Peserta didik dapat menceritakan apa yang mereka rasakan dan menuliskannya dalam bagian akhir LKPD yang mereka kerjakan. Hal ini dapat menjadi evaluasi untuk pendidik untuk mengetahui langkah-langkah yang perlu diambil untuk menindaklanjuti permasalahan yang dialami peserta didik. Seperti yang Darmiah paparkan bahwa pengalaman belajar sangat menunjang perkembangan emosi peserta didik (Darmiah, 2019).

LKPD ini mengarahkan peserta didik untuk mampu memahami konsep dari materi dengan melakukan aktivitas-aktivitas yang 
alat dan bahannya disesuaikan dengan kondisi peserta didik dan bersifat umum, tidak hanya bisa ditemukan di sekolah, namun juga di rumah. Kegiatan sudah disesuaikan dengan indikator setiap materi. Langkah-langkah dibuat sesederhana mungkin agar mudah dipahami peserta didik dan pendamping belajar mereka. Kegiatan yang ditampilkan dalam Lembar Kerja Peserta Didik Berbasis Moodle tidak berbeda jauh dengan Lembar Kerja Peserta Didik cetak yang digunakan di sekolah. LKPD Berbasis Moodle berbentuk non-cetak sehingga mudah dikerjakan dimanapun dan kapanpun oleh peserta didik tanpa terbatas ruang dan waktu.

LKPD ini memuat mengenai materi pengukuran panjang. Pemilihan materi ini didasarkan pada kelengkapan alat dan bahan yang umum dimiliki peserta didik. Pada saat melakukan observasi, hampir seluruh peserta didik memiliki alat dan bahan yang diperlukan dalam LKPD. Alat dan bahan ini sudah tersedia di rumah dan merupakan alat dan bahan yang umum dijumpai, cara penggunaannya sudah dimengerti oleh peserta didik dan pendamping belajar mereka, harganya murah apabila mereka harus memilikinya, dan dapat digunakan bergantian dengan teman mereka. Peserta didik juga sudah memiliki bekal materi mengenai pengukuran panjang di kelas II dan III walau materi yang dipaparkan belum terlalu kompleks.

Pada tahap Design ini terdiri dari dua langkah, yaitu instalasi Moodle dan penyusunan LKPD. Tahap desain ini selama kurang lebih 3 bulan karena membutuhkan banyak pertimbangan terkait kesesuaian dengan peserta didik. LKPD ini merupakan hal yang masih sangat baru diterapkan di dunia sekolah dasar.

Untuk instalasi Moodle, dilakukan pengunduhan aplikasi dari Google kemudian menjalankannya menggunakan XAMPP sebagai localhost. Setelah desain Moodle selesai didesain dalam localhost, Moodle dipindahkan ke hosting berbayar karena membutuhkan memori yang lebih besar kapasitasnya dan agar LMS Moodle dapat diakses oleh seluruh pengguna terdaftar dalam Moodle.

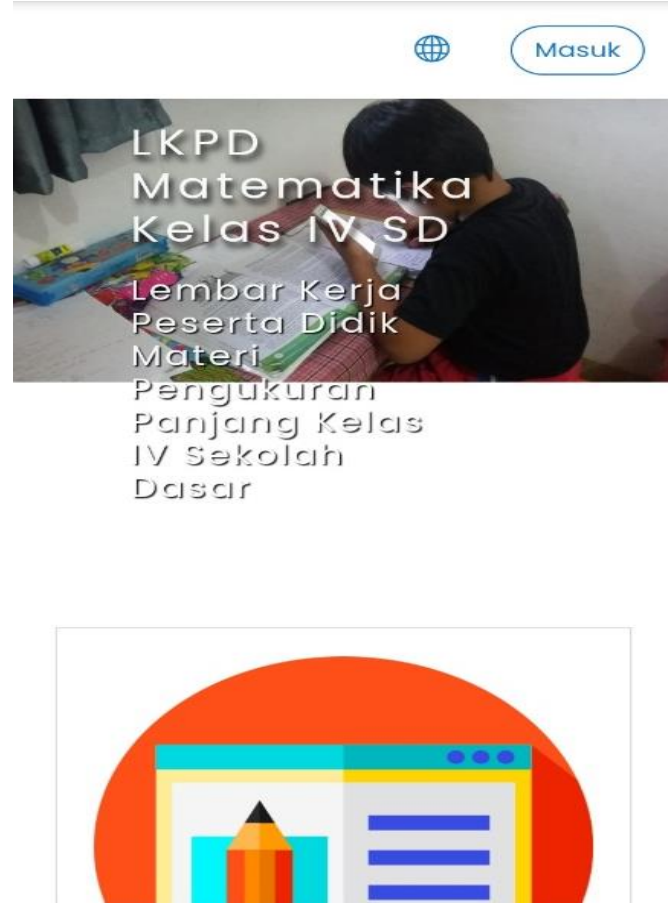

Gambar 3: Tampilan Halaman Depan Moodle saat Diakses dengan Smartphone

Untuk penyusunan LKPD, draf LKPD yang dibuat secara kasar dikembangkan menjadi desain yang lebih halus. Setiap materi LKPD disesuaikan dengan setiap indikator. LKPD berbasis Moodle disusun menggunakan beberapa aplikasi penunjang seperti Microsoft Word 2013, Adobe Photoshop, dan Corel Draw. Microsoft Word 2103 diantaranya digunakan untuk menyusun indikator dan komponen LKPD lainnya.

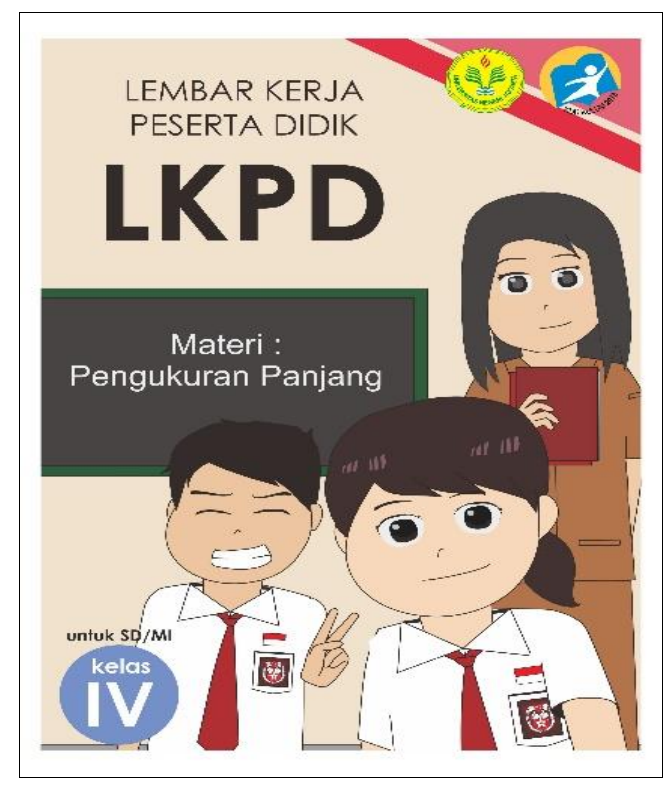

Gambar 4: Sampul LKPD 


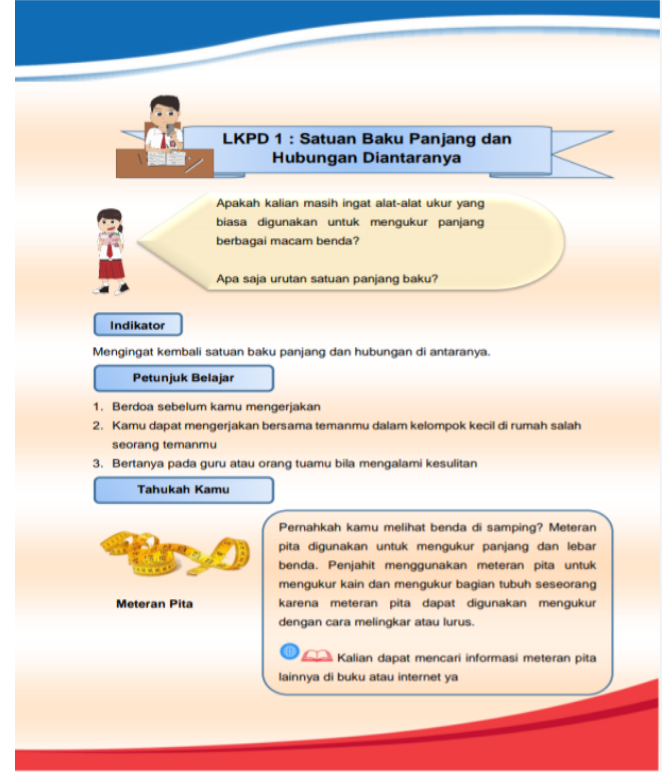

Gambar 5: Tampilan LKPD 1

\section{Tahap Pengembangan (Development)}

Pada tahap Development, membahas tentang hasil pengembangan dan memproduksi produk yang akan digunakan. Pada tahap ini, mulai dikembangkan produk LKPD berbasis Moodle sesuai rancangan yang telah dibuat. Setelah itu LKPD yang telah selesai dikembangkan lalu diproduksi. Pada tahap ini juga dilakukan evaluasi produk oleh ahli bahasa, ahli materi, dan ahli media (expert review). Untuk penilaian dengan para ahli digunakan instrumen penelitian yang berupa lembar validasi untuk penilaian para ahli.

Pada tahap ini, dilakukan penilaian produk secara pribadi, lalu disempurnakan sesuai arahan dosen pembimbing sebelum melaksanakan expert review. Setelah itu dilakukan expert review kepada ahli media, ahli bahasa, dan ahli materi. Dalam tahap ini, didapat persentase kelayakan dari ahli media sebesar $85 \%$, dari ahli bahasa sebesar 90\%, dan dari ahli materi sebesar 91\%. Total akumulasi dari expert review oleh para ahli adalah sebesar $88,46 \%$ dan pengembangan LKPD ini berada dalam kategori sangat layak.

Pada tahap selanjutnya dilakukan uji coba produk, melalui uji coba ini dilakukan pada 27 responden peserta didik kelas IV SD. Uji penggunaan dilakukan terhadap peserta didik kelas IV SD. Tujuan uji coba penggunaan adalah untuk mengetahui kelayakan LKPD yang telah dikembangkan berdasarkan penilaian peserta didik menggunakan angket respon.

\section{Tahap Implementasi (Implemention)}

Tahap Implemention pertama adalah face to face tryout yang melibatkan 3 orang peserta didik. Uji coba ini dilaksanakan pada tanggal 11 Agustus 2021. Peserta didik yang dilibatkan dalam penelitian ini adalah peserta didik yang memiliki tingkat kemampuan berbeda-beda. Pada tahap ini memperoleh persentase kelayakan sebesar $94 \%$ dengan beberapa masukan dari peserta didik dan pendamping belajar mereka. Dua dari tiga peserta didik memberi kritik pada penyampaian cara penggunaan yang menggunakan teks dianggap sulit dipahami, sehingga perlu dibuatkan video dengan aplikasi Tiktok yang memuat video tutorial cara penggunaannya. Hal ini didukung oleh penelitian yang dilakukan Parida, dkk, yang menyatakan bahwa video tutorial memberi pengaruh dalam pembelajaran. Video tutorial memberi dampak yang lebih baik dalam menyampaikan materi kepada peserta didik daripada buku teks (Parida et al., 2019).

Implementasi selanjutnya adalah pada tahap uji lapangan. Peserta yang dilibatkan dalam penelitian ini adalah 24 peserta didik kelas IV-B SDN Baru 08 Pagi yang tidak dilibatkan dalam face to face tryout. Uji coba ini dilaksanakan pada tanggal 19 Agustus 2021 melalui Google Meet. Uji coba ini menggunakan produk yang sudah diperbaiki berdasarkan masukan peserta didik dan pendamping belajar mereka pada tahap face to face tryout. Berdasarkan hasil evaluasi ini didapat kelayakan sebesar $94 \%$.

Berdasarkan tahap implementasi yang telah dilakukan, LKPD yang dikembangkan berada dalam kategori sangat layak. Untuk tahap implementasi didapat kelayakan sebesar 94\% dari face to face tryout dan sebesar $94 \%$ dari field trial. Apabila diakumulasikan, persentase kelayakan dalam tahap implementasi adalah sebesar $94 \%$ dan dalam kategori sangat layak. Untuk tanggapan pendidik terhadap kualitas produk, pengembangan LKPD memperoleh persentase kelayakan sebesar 91,6\%. 


\section{Tahap Evaluasi (Evaluation)}

Pada tahap Evaluation ini dilakukan evaluasi yaitu dilakukan untuk melihat apakah LKPD yang tengah dikembangkan berhasil, sesuai dengan harapan awal atau tidak. Sebenarnya tahap evaluasi terjadi pada empat tahap sebelumnya, namun evaluasi sebelumnya hanya untuk kebutuhan revisi. Hal ini senada dengan pernyataan Jurianto bahwa evaluasi merupakan tahap terakhir, namun sebenarnya memainkan peran pada empat tahap sebelumnya (Kirkpatrick \& Kayser, 2016).

\section{Analisis Data}

Berdasarkan hasil analisis kebutuhan pendidik, pengembangan produk LKPD belum pernah diterapkan selama pembelajaran jarak jauh, maupun saat pembelajaran tatap muka. Peserta didik kelas IV SDN Baru 08 Pagi belajar tanpa menggunakan buku melainkan bersumber dari informasi yang dikirim pendidik di grup kelas karena keterbatasan jumlah buku yang diterima oleh sekolah. Untuk memahami materi, pendidik akan memberikan soal-soal dan penugasan disertai sumber yang berkaitan dengan materi yang diajarkan untuk membangun pemahaman konsep peserta didik. Soalsoalnya langsung mengarahkan peserta didik untuk mampu menjawab soal-soal, tidak terlebih dahulu untuk mengajak peserta didik membangun pemahaman.

Untuk LKPD sendiri belum pernah digunakan pendidik dalam pembelajaran di kelas, baik dalam pembelajaran saat tatap muka atau pembelajaran jarak jauh. Keterbatasan buku juga dialami di kelas IV-B SDN Baru 08 Pagi, sehingga untuk sumber belajar, pendidik akan menggunakan soal-soal yang dikutip pendidik dari berbagai buku dan internet. Tipe soal yang diberikan juga bervariasi seperti soal cerita dan soal bergambar. Soal-soal yang diberikan pendidik merupakan tipe soal yang langsung menyertakan jawaban, bukan soal yang terlebih dahulu membangun pemahaman konsep peserta didik mengenai materi.

Dalam wawancara dan observasi terbuka, peserta didik juga menceritakan pembelajaran di kelas. Pembelajaran bersama pendidik biasanya diberikan tugas-tugas untuk memperdalam materi. Saat melakukan pengamatan pada soal-soal yang diberikan, soal-soal yang bersifat langsung menjawab, tidak terlebih dahulu membangun pemahaman peserta didik. Soal-soal seperti ini sebaiknya diarahnya ke tahap selanjutnya setelah peserta didik diberikan soal yang membangun pemahaman peserta didik.

Produk ini melewati beberapa evaluasi seperti revisi produk secara mandiri yang didasarkan pada kesadaran pribadi, evaluasi oleh dosen pembimbing yang memberi masukan sebelum produk dilanjutkan ke tahap selanjutnya, evaluasi oleh para ahli, dan terakhir adalah evaluasi berdasarkan masukan dari peserta didik dan pendidik. Revisi-revisi ini sangat berguna untuk penyempurnaan produk yang tengah dikembangkan.

Selanjutnya adalah tahap expert review oleh ahli bahasa. Validasi diadakan dengan ahli bahasa yang merupakan dosen Bahasa Universitas Katolik Atma Jaya Jakarta. Expert Review berlangsung via chat Whatsapp dan email pada tanggal 27 Juni 2021. Beberapa pertanyaan diajukan oleh validator melalui pesan via email. Perbaikan menitikberatkan pada penggunaan kata atau kalimat yang dinilai kurang tepat, memiliki makna ganda, dan kurang komunikatif. Penilaian ini tidak hanya dalam LKPD, namun bahasa dalam Moodle juga diberikan masukan. Untuk rinciannya adalah pada aspek bahasa dan komunikasi memperoleh kelayakan 91,7\% dan aspek keterbacaan adalah $87,5 \%$ yang apabila diakumulasi keseluruhan maka persentase kelayakan adalah $90 \%$.

Expert review selanjutnya adalah dengan ahli materi yang merupakan dosen matematika Teknik Informatika, Fakultas Teknik dan Ilmu Komputer, Universitas Indraprasta PGRI. Perbaikan menitikberatkan pada penggunaan gambar yang belum sesuai materi, perintah yang kurang tepat, dan contoh soal yang belum tepat. Untuk rinciannya adalah aspek isi memperoleh persentase kelayakan sebesar 88,9\% dan aspek kesesuaian memperoleh persentase kelayakan 95\% sehingga apabila diakumulasikan maka totalnya adalah $91 \%$ untuk validasi materi. 
Expert review terakhir dilakukan oleh ahli media yang merupakan dosen Teknologi Pendidikan, Fakultas Pendidikan dan Bahasa, Universitas Katolik Atma Jaya Jakarta. Expert review dilakukan secara tatap muka melalui pertemuan virtual dengan Zoom selama kurang lebih dua jam. Aspek yang perlu direvisi kurang lebih meliputi penggunaan Moodle dan LKPD yang penyampaiannya perlu lebih diperjelas. Saran yang ditegaskan oleh validator adalah penyampaian yang harus berulang untuk menguatkan pemahaman peserta didik dan pendamping belajar peserta didik mengenai penggunaan LKPD berbasis Moodle ini. Pemahaman pendamping belajar di sini adalah orang tua atau keluarga yang mendampingi peserta didik belajar selama PJJ, hal ini merupakan sesuatu yang umum karena berdasarkan hasil observasi dan wawancara yang dilakukan menyatakan bahwa sebagian besar peserta didik tidak memiliki ponsel pribadi. Mereka memiliki ponsel namun milik orang tua atau milik saudara mereka yang digunakan bergantian dengan saudara mereka yang lain.

Untuk rincian validasi media adalah aspek kualitas media memperoleh persentase kelayakan sebesar $87,5 \%$, aspek kesesuaian memperoleh persentase kelayakan 81,25\%, aspek penyajian gambar adalah $100 \%$, dan aspek penggunaan $75 \%$. Hasil akumulasi dari seluruh aspek totalnya adalah $85 \%$ untuk validasi media.

Setelah expert review, produk kembali diperbaiki sesuai masukan pada tahap one to one tryout oleh peserta didik dibantu oleh pendamping belajar peserta didik. Pada tahap ini dipilih tiga peserta didik yang memiliki tingkat kemampuan matematika berbeda-beda yaitu GNMR, MWRA, dan MAA. One to one tryout dilaksanakan di rumah peserta didik masing-masing yang berlokasi di sekitar Kelurahan Baru, Kecamatan Pasar Rebo, Jakarta Timur.

Peserta didik yang memiliki tingkat kemampuan berbeda-beda juga merespon setiap aktivitas dalam LKPD dengan berbeda. GNMR adalah peserta didik yang sangat menyukai materi pengukuran ini karena ketertarikannya pada penggunaan meteran dan penggaris. Hal ini juga didasari ibunda
GNMR sendiri yang merupakan pedagang pakaian di toko online sehingga memberi dampak kepada GNMR yang menjadi mahir dalam menggunakan alat dan bahan yang tercantum dalam LKPD. MWRA adalah peserta didik selanjutnya yang terlibat dalam one to one tryout. MWRA adalah peserta didik yang mudah memahami materi namun sedikit pendiam sehingga diperlukan mengelola suasana agar one to one tryout tidak terlalu tegang untuk MWRA. MAA merupakan peserta didik yang tergolong aktif bergerak, namun saat one to one tryout, MAA mampu memahami materi dan instruksi yang diberikan untuk mengerjakan aktivitas di LKPD. Orang tua MAA yang memiliki peran sebagai pendamping belajar juga turut serta mendampingi MAA dan memberi penjelasan ulang mengenai instruksi yang diberikan agar MAA mudah memahami soal. Dari tahap one to one tryout diperoleh hasil bahwa instruksi penggunaan LKPD sangat sulit apabila hanya diberikan dalam bentuk tulisan, sehingga dibuatkan video Tiktok mengenai tutorial penggunaan agar lebih mudah dipahami peserta didik di tahap selanjutnya.

Tahap terakhir dalam tahap reduksi data mengenai hasil produk yang dikembangkan ini adalah field trial. Field trial melibatkan 24 peserta didik tanpa melibatkan tiga orang peserta didik yang telah diikutsertakan dalam one to one tryout. Field trial ini berlangsung virtual menggunakan Google Meet selama kurang lebih satu jam. Peserta didik diarahkan untuk mendengarkan cara penggunaan LKPD terlebih dulu sebelum mereka mencoba mandiri dengan pendamping belajar mereka di rumah. Langkah ini dipilih karena sebagian besar peserta didik tidak memiliki dua ponsel yang dapat digunakan bersamaan (satu ponsel untuk pertemuan virtual dan satu ponsel untuk mengerjakan). Bila mereka punya dua ponsel, salah satunya adalah milik keluarga mereka yang ponselnya bisa digunakan.

Hasil perbaikan pada tahap sebelumnya memberi dampak yang lebih baik kepada peserta didik dalam tahap field trial. Hampir seluruh peserta didik mampu memahami cara penggunaan LKPD melalui teks yang terdapat dalam LKPD dan Moodle dibantu dengan video cara penggunaan yang telah dibuat. Sebelumnya dalam pertemuan virtual, telah 
ditekankan beberapa poin penting yang rawan menjadi kesalahan pengguna LKPD berbasis Moodle yaitu kesalahan dalam memasukkan username dan password yang menjadi kunci awal tidak bisa diaksesnya LKPD berbasis Moodle. Dengan antisipasi sejak awal, peserta didik dapat mengakses LKPD dengan baik dan mencoba aktivitas yang berada dalam LKPD.

\section{SIMPULAN DAN SARAN}

Data pada analisis kebutuhan digunakan untuk dianalisis dan menghasilkan sebuah rumusan masalah yaitu mengembangkan LKPD Berbasis Moodle untuk peserta didik kelas IV sekolah dasar pada materi pengukuran panjang. LKPD ini dapat diakses kapan saja dan dimana saja menyesuaikan dengan kebutuhan peserta didik.

Langkah selanjutnya setelah tahap analisis adalah mendesain LKPD sesuai analisis kebutuhan. Tahap desain dilakukan dengan tujuan untuk merancang produk LKPD sesuai dengan kebutuhan peserta didik dan pendidik, sehingga LKPD yang dikembangkan bisa digunakan oleh peserta didik. Proses desain LKPD dari instalasi Moodle dan penyusunan LKPD selama kurang lebih tiga bulan. Hal memakan waktu yang cukup lama karena membutuhkan banyak pertimbangan dan masukan dari dosen pembimbing mengenai LKPD yang baik dan layak digunakan untuk peserta didik kelas IV sekolah dasar. Untuk mengetahui kelayakan LKPD, diperlukan untuk melanjutkan ke tahap selanjutnya yaitu tahap pengembangan.

Tahap pengembangan ini membahas tentang hasil pengembangan dan memproduksi produk yang akan digunakan. Pada tahap ini juga dilakukan evaluasi produk oleh ahli bahasa, ahli materi, dan ahli media (expert review). Untuk penilaian dengan para ahli digunakan instrumen penelitian yang berupa lembar validasi untuk penilaian para ahli. Dalam tahap ini, didapat persentase kelayakan dari ahli media sebesar $85 \%$, dari ahli bahasa sebesar $90 \%$, dan dari ahli materi sebesar 91\%. Hasil rekapitulasi dari expert review oleh para ahli adalah sebesar $88,46 \%$ dan pengembangan LKPD ini berada dalam kategori sangat layak. Maka dapat disimpulkan bahwa lembar kerja peserta didik berbasis Moodle materi pengukuran panjang kelas IV sekolah dasar sangat layak digunakan untuk diterapkan di tahap selanjutnya yaitu tahap implementasi.

Tahap selanjutnya dilakukan uji coba produk, melalui uji coba ini dilakukan pada 27 responden peserta didik kelas IV SD. Tahap implementasi terdiri dari 2 tahap penelitian, yaitu pertama tahap face to face tryout yang melibatkan 3 orang peserta didik SDN Baru 08 Pagi. Untuk tahap kedua yaitu uji lapangan (field trial) menggunakan 24 orang peserta didik karena 3 orang peserta didik yang telah digunakan dalam tahap face to face tryout sudah tidak dilibatkan kembali.

Pada face to face tryout dipilih tiga peserta didik kelas IV-B SDN Baru 08 Pagi. Pada tahap ini menghasilkan persentase kelayakan sebesar 94\%. Field trial dilakukan pada 24 peserta didik kelas IV-B SDN Baru 08 Pagi yang tidak terlibat dalam face to face tryout. Berdasarkan hasil uji coba ini didapat kelayakan sebesar 93,6\% dari peserta didik dan persentase kelayakan $91,6 \%$ dari pendidik. Berdasarkan hasil rekapitulasi produk nilai kelayakan produk maka dapat disimpulkan bahwa lembar kerja peserta didik berbasis Moodle materi pengukuran panjang kelas IV sekolah dasar sangat layak digunakan untuk diterapkan dalam pembelajaran matematika.

Berdasarkan hasil penelitian mengenai kelayakan LKPD ini disarankan beberapa hal bagi beberapa pihak. Bagi kepala sekolah disarankan untuk mendukung penggunaan LKPD ini terutama untuk sekolah yang sudah memiliki fasilitas laboratorium komputer sendiri dengan menginstruksi setiap pendidik kelas IV pada pembelajaran matematika. Bagi pendidik disarankan menggunakan LKPD ini dalam pembelajaran matematika dan sebagai referensi dalam membuat LKPD pada materi lain. Bagi peneliti selanjutnya disarankan untuk melakukan penelitian eksperimen untuk mengetahui tingkat efektivitas produk pengembangan LKPD berbasis Moodle ini.

\section{DAFTAR PUSTAKA}

Arifa, F. N. (2020). Tantangan Pelaksanaan Kebijakan Belajar Dari Rumah Dalam Masa Darurat Covid-19. Info 
Singkat;Kajian Singkat Terhadap Isu Aktual Dan Strategis, XII(7/I), 6. Google

Aryani, F., \& Hiltrimartin, C. (2011). Pengembangan LKS untuk metode penemuan terbimbing pada pembelajaran matematika kelas VIII di SMP Negeri 18 Palembang. Jurnal Pendidikan Matematika, 5(2). https://doi.org/10.22342/jpm.5.2.578.

Aydede, M. N. (2010). THE EFFECT OF ACTIVE LEARNING BASED ACTIVITIES ON STUDENTS' LEARNING LEVELS IN PRIMARY SCHOOL SIXTH GRADE SCIENCE COURSE . Education Sciences, 5 (4), 2245-2253

https://dergipark.org.tr/en/pub/nwsaedu/ issue/19822/212276

Branch, R. M. (2009). Intructional Design: The ADDIE Approach. Springer US. Google Scholar.

Damayanti, A. E., Syafei, I., Komikesari, H., \& Rahayu, R. (2018). Kelayakan Media Pembelajaran Fisika Berupa Buku Saku Berbasis Android Pada Materi Fluida Statis. Indonesian Journal of Science and Mathematics Education, 1(1), 6370.

http://www.ejournal.radenintan.ac.id/ind ex.php/IJSME/article/view/2476

Darmiah, D. (2020). PERKEMBANGAN DAN FAKTOR-FAKTOR YANG MEMPENGARUHI EMOSI ANAK USIA MI. PIONIR: JURNAL PENDIDIKAN, 8(2).. https://jurnal.arraniry.ac.id/index.php/Pionir/article/vie w/6230

Dermawati, N., Suprata, S., \& Muzakkir, M. (2019). Pengembangan Lembar Kerja Peserta Didik (LKPD) Berbasis Lingkungan. JPF (Jurnal Pendidikan Fisika) Universitas Islam Negeri Alauddin Makassar, 7(1), 74-78. http://journal.uin-

alauddin.ac.id/index.php/PendidikanFisi $\mathrm{ka} /$ article/view/3143

Fredy, F., Prihandoko, L. A., \& Anggawirya, A. M. (2020). The Effect of Learning Experience on the Information Literacy of Students in the Ri-Png Border During Covid-19 Period.International Journal of Multicultural and Multireligious Understanding,7(10), 171-180. http://dx.doi.org/10.18415/ijmmu.v7i10. 2067

Kirkpatrick, J. D., \& Kirkpatrick, W. K. (2016). Kirkpatrick's four levels of training evaluation. Association for Talent Development. Google Scholar

KPAI. (2020). Survei Pelaksanaan Pembelajaran Jarak Jauh (PJJ) dan Sistem Penilaian Jarak Jauh Berbasis Pengaduan KPAI. kpai.go.id

Mardawani, M. (2020). Praktis Penelitian Kualitatif Teori Dasar Dan Analisis Data Dalam Perspektif Kualitatif. Yogyakarta: Deepublish. Google Scholar

Meriyati, M. (2015). Memahami Karakteristik Anak Didik. Lampung : IAIN Raden Intan. Google Scholar

Parida, L., Sahono, B., \& Sapri, J. (2019). Pengaruh Pembelajaran Video Tutorial Terhadap Prestasi Belajar. Jurnal Pendidikan, Teknologi, 8(1), 12-21. Google Scholar

Restianti, R., Salam, M., \& Suhar, S. (2019, December). Pengaruh Model Pembelajaran Integratif Terhadap Hasil Belajar Matematika. In Seminar Nasional Pendidikan Matematika II Tahun 2019. http://ocs.uho.ac.id/index.php/snpmat2/ SNPMAT2/paper/viewPaper/113

Sari, R. P., Tusyantari , N. B., \& Suswandari, M. (2021). DAMPAK PEMBELAJARAN DARING BAGI SISWA SEKOLAH DASAR SELAMA COVID-19. Prima Magistra: Jurnal Ilmiah Kependidikan, 2(1), 9-15. https://doi.org/10.37478/jpm.v2i1.732

SELFIA, M. (2019). PENGEMBANGAN LEMBAR KERJA PESERTA DIDIK DENGAN PENDEKATAN KONTEKSTUAL MATA PELAJARAN MATEMATIKA KELAS 
IV SISWA SD/MI (Skripsi, UIN Raden Intan Lampung). Google Scholar

Tarigan, D., Rangkuti,I., \& Siregar, A. (2018). MENINGKATKAN HASIL BELAJAR SISWA DENGAN MENGGUNAKAN MODEL

REALISTIC MATHEMATICS EDUCATION (RME) PADA MATA PELAJARAN MATEMATIKA DI KELAS V SDS SALSA CINTA RAKYAT. ELEMENTARY SCHOOL JOURNAL PGSD FIP UNIMED, 8(4), 242-259.

https://doi.org/10.24114/esjpgsd.v8i4.11 878

Tumijan, P., \& Purwanto, A. (2019). PENGEMBANGAN E-LEARNING BERBASIS MOODLE SEBAGAI UPAYA INOVATIF UNTUK MENINGKATKAN HASIL BELAJAR IPA PADA MATERI RANGKAIAN LISTRIK SEDERHANA UNTUK SISWA KELAS VI SD PENABUR
JAKARTA. PROCEEDINGS-OPEN ACCESS JOURNAL, 1(01), 50-55. https://journal.unpak.ac.id/index.php/pro ceedings/article/view/1137

Widjajanti, E. (2008, December). Kualitas lembar kerja siswa. In Makalah Seminar Pelatihan penyusunan LKS untuk Guru SMK/MAK pada Kegiatan Pengabdian Kepada Masyarakat Jurusan Pendidikan FMIPA Universitas Negeri Yogyakarta (pp. 2-5). Google Scholar

Widodo, S. (2017). Pengembangan Lembar Kegiatan Peserta Didik (LKPD) berbasis Pendekatan Saintifik untuk Meningkatkan Keterampilan Penyelesaian Masalah Lingkungan Sekitar Peserta Didik di Sekolah Dasar. Jurnal Pendidikan Ilmu Sosial, 26(2), 189-204. Google Scholar 